\title{
The taxonomy of Xanthosia huegelii and closely related species (Apiaceae: Hydrocotyloideae)
}

\author{
J.M. Hart
}

\begin{abstract}
J.M. Hart (John Ray Herbarium, School of Biological Sciences, Macleay Building A12, The University of Sydney, NSW 2006, Australia; e-mail: jmh@bio.usyd.edu.au). 2000. The taxonomy of Xanthosia huegelii and closely related species (Apiaceae: Hydrocotyloideae). Telopea 8(4): 441-453. Recognition of the three species Xanthosia huegelii, X. pusilla and X. tasmanica has been inconsistent across their distribution in southern Australia. As part of a revision of the genus, the history of this group of species is reviewed and the position of the competing names clarified. Examination of the morphology of the species, both from living and herbarium material, resulted in only two taxa being recognised, $X$. huegelii and X. tasmanica. Both species are more widely distributed than previously thought, due mainly to the misapplication of the name X. pusilla.
\end{abstract}

\section{Introduction}

Xanthosia huegelii (Benth.) Steud., X. pusilla Bunge and X. tasmanica Domin are small herbaceous species, commonly occurring in eucalypt forest and heath communities in southern Australia. These species are distinguished from all other members of the genus by their trifoliolate leaves with entire segments.

In the course of a revision of the genus, the delimitation of the currently recognised species was found to be inconsistent. There has been much confusion in distinguishing the three species from one another, particularly in the application of the competing names X. tasmanica and X. pusilla, considered as distinct taxa in some treatments (e.g. Eichler 1986) and a single species, X. pusilla, in others (e.g. Curtis 1963).

This paper aims to clarify the application of the competing names based on field observations and herbarium material, including examination of the relevant type specimens.

\section{Taxonomic history}

Leucolaena huegelii was described by Bentham in 1837 from specimens collected in the Swan River and King Georges Sound areas in Western Australia. Bentham described the species as having trifoliolate leaves with linear segments, and pedunculate compound umbels with 3-5 rays and two flowers in each umbellule. Steudel (1841: 790-791) transferred the species from the illegitimate genus Leucolaena R. Br. to Xanthosia Rudge.

Bunge (1845) described two new species, X. pusilla and X. glabrata. Xanthosia pusilla was described as possessing oblong leaf segments and a sessile, simple umbel with 1-2 flowers. Xanthosia glabrata was described as a glabrous herb with oblong-linear leaf segments and pedunculate simple umbels with 1-3 flowers. Both species were based on specimens from Western Australia. 
Turczaninov (1849) described X. villosa, a herb with trifoliolate leaves with linearcuneate segments and pedunculate, simple umbels of two flowers. However, his type specimen, Drummond's 4th collection no. 133, was also cited within the same publication as the type for Dimetopia grandis, the base name for Trachymene grandis (Turcz.) Rye (Rye 1999). Examination of photographs of this collection confirms it to be a Trachymene having simple umbels with numerous flowers. A survey of Turczaninov's type specimens at KW found the intended type of X. villosa to be Drummond's 4th collection no. 139 (Marchant 1990), a specimen collected at Swan River in Western Australia which conforms to Turczaninov's description. As it can only be considered illogical for Turczaninov to have intended to publish these apparently homotypic synonyms in the same work, the type citation for $X$. villosa should be treated as a typographical error. Thus the type for the name $X$. villosa is here lectotypified as Drummond's 4th collection no. 139.

Bentham (1867) listed X. villosa in synonymy under X. pusilla, and X. glabrata was reduced to varietal status as X. pusilla var. glabrata. The two species he recognised in his treatment, X. huegelii and X. pusilla, were separable by the inflorescence being a simple umbel (in X. pusilla) or a compound umbel (X. huegelii). Xanthosia huegelii was considered to be restricted to Western Australia, whereas X. pusilla was stated to occur in Western Australia, South Australia, Victoria and Tasmania.

Xanthosia tasmanica was based upon specimens collected at Circular Head and Georgetown in Tasmania (Domin 1907). This species was described as having: elliptical leaf segments with the lateral segments sometimes bifid; subsessile, 1-2flowered umbels; and five-ribbed fruit. Ostenfeld (1921) reported X. tasmanica as occurring in Western Australia and agreed that the species was different from $X$. pusilla. However, X. tasmanica has not ever been subsequently considered to occur in Western Australia.

Recently Keighery informally divided the X. huegelii specimens in PERTH (sheet annotations) into three unpublished subspecies; X. huegelii 'subsp. huegelii' with linear leaflets and a compound umbel; X. huegelii 'subsp. aurea', a variant occurring in the Eneabba to Gingin area north of Perth, having inflorescences with more numerous flowers and broader bracteoles; and an unnamed subspecies 'Southern' with broadly elliptic leaflets, occurring in coastal areas in the south of the state.

\section{Discussion}

The main features used by previous workers to distinguish the three taxa (X. huegelii, $X$. pusilla and X. tasmanica) were leaf segment shape and inflorescence elaboration. Specimens could be divided into two groups based on leaf segment shape; those with elliptic leaf segments, and those with linear, oblong, lanceolate or oblanceolate leaf segments (Figs 1 and 2). Within the group with elliptic leaf segments (Fig. 1), the lateral segments of the leaves on young plants are often partly to fully divided into two lobes. The leaves of this group are covered by a sparse covering of long multicellular, multiseriate trichomes. The group with linear, oblong, lanceolate or oblanceolate leaf segments (Fig. 2) is densely villous to glabrous, sometimes becoming glabrous with age. Very rarely, the segments may be broadly toothed (Fig. $2 \mathrm{~g}$ ). The stems and taproot of many of the plants with this leaf form excorticate with age. As this does not occur in young plants or the new growth from which the inflorescences arise, it is not always evident on herbarium specimens. The two leaf forms occur at the same locality on separate individuals without the presence of intermediate leaf forms (Hart 95108 \& 95109). 

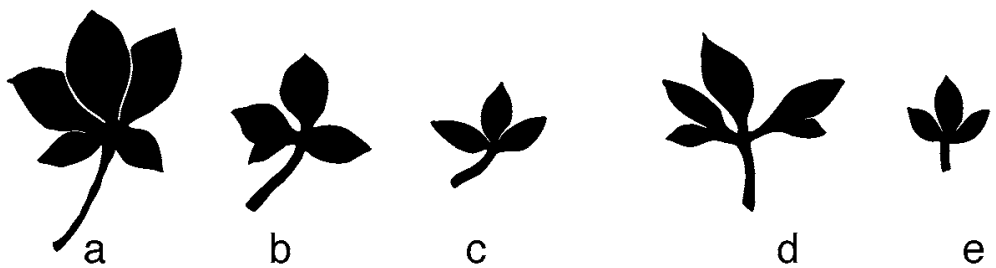

Fig. 1. Leaf silhouettes of Xanthosia tasmanica showing variation within and between individuals: a, basal; b, mid-branch; c, subtending inflorescence (from Hart 95109); d, basipetal, e, acropetal (from Hart 369). All leaves actual size.

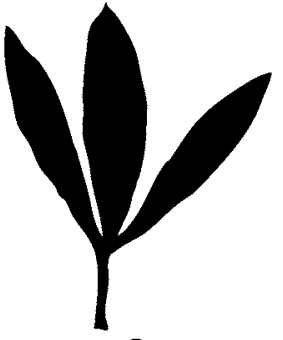

a

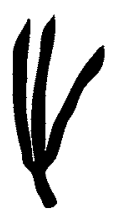

e

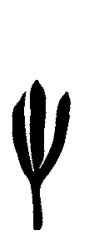

b

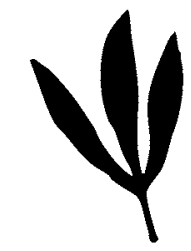

C

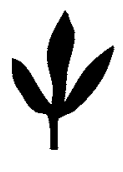

d

Fig. 2. Leaf silhouettes of Xanthosia huegelii showing variation within and between individuals. a, basipetal; b, acropetal (from Hart 95055); c, basipetal; d, acropetal (from Hart 381); e, basipetal; f, acropetal (from Hart 95134); g, basipetal; h, acropetal (from Hart 95142). All leaves actual size.

The inflorescences vary in the extent of elaboration (simple or compound) and size (rays up to $5 \mathrm{~mm}$ long) in individuals of both leaf forms. Within the group with elliptic leaf segments, inflorescences vary from one- to four-rayed with one flower per ray (umbellule) and with one flower sometimes present between the rays. The flowers are all bisexual and the involucral bracts and bracteoles are all linear. The group with linear, oblong, lanceolate or oblanceolate leaf segments also has 1-4 rays in the inflorescences with 1 or 2 bisexual flowers in each umbellule, sometimes with one flower between the rays. At the north-western extreme of its distribution, in the Eneabba area north of Perth, the inflorescences are larger with broader, elliptic bracteoles, and up to six bisexual and/or male flowers in each rayed umbellule and up to three flowers between the rays. Continuous variation in flower number and between elliptic and linear involucral bracts and bracteoles occurs such that division of this group is largely arbitrary. The flowers of the two leaf forms are morphologically consistent, while the fruit vary in rib number; one form has 5-7 ribs, whereas the other has 5-9 ribs. 
The two leaf forms are here considered to be sufficiently distinct to be treated as two separate - but closely related - species, which accord with the types of X. tasmanica (with elliptic leaf segments), and X. huegelii (with linear, oblong, lanceolate or oblanceolate leaf segments).

Keighery (1982) determined the chromosome numbers for many Western Australian Apiaceae, and lists all but one species of Xanthosia as having $n=10$. Only X. pusilla was found to have $n=20$. The chromosome voucher specimens were redetermined in line with the two species recognised here. The chromosome numbers for X. huegelii are both $n=10$ (seven specimens) and $n=20$ (10 specimens), and for X. tasmanica are also $n=10$ and $n=20$ (one specimen and two specimens respectively; Table 1 ).

Table 1. Current determinations of chromosome voucher specimens following the author's concepts.

Chromosome numbers taken from Keighery (1982) and from sheet information where available.

Locality

\section{Xanthosia huegelii}

$16 \mathrm{~km} \mathrm{NW}$ of Cataby, W.A.

$170 \mathrm{~km} \mathrm{~N}$ of Perth on Brand Highway, W.A.

$5 \mathrm{~km}$ S of Corbanup River Store,

Busselton/Margaret River Road, W.A.

8.5 miles [13.6 km] N of Eneabba, W.A.

Cannington Swamp, W.A.

24 miles [38 km] S of Nannup on Pemberton road, W.A.

1.2 miles [1.9 km] W of Brand Highway on Mimegarra road, W.A.

Inlet River, Walpole to Manjimup, W.A.

$32 \mathrm{~km} \mathrm{~N}$ of Walpole, W.A.

Mt Burnett Wittenoom Hills

c.70 km NE Esperance, W.A.

Mt Merivale c. $30 \mathrm{~km}$ E of Esperance, W.A.

395 mile peg, Ravensthorpe to Esperance road, W.A.

47.2 miles [75.5 km] E of Albany

on Jerramungup road, W.A.

22 miles [35 km] E of Esperance, W.A.

$10.2 \mathrm{~km} N$ Walpole on Manjimup road, W.A.

Nicholls road Mt Lofty Ranges, S.A.

Mt Merivale E of Esperance, W.A.

\section{Xanthosia tasmanica}

18 miles [29 km] S of turnoff to Busselton on Yallingup to Karridale Road, W.A.

$46 \mathrm{~km}$ W of Ravensthorpe, W.A.

25 km NW Denmark on Walpole Road, W.A.

Not located: listed as X. pusilla by Keighery (1982)

Nannup, W.A

24 km S of Manjimup, W.A. n

Voucher and Herbarium

10

G.J. Keighery S.n.,PERTH 3620700

10

G.J. Keighery 97, PERTH 4878728

10

G.J. Keighery 690, KPBG

10

G.J. Keighery 1338, PERTH 3620506

G.J. Keighery 2102,PERTH 3620581

10

G.J. Keighery 2166, PERTH 3620891

10

G.J. Keighery 2753, PERTH 3620530

20

G.J. Keighery 351, PERTH 3621278

20
G.J. Keighery 81, PERTH 4878744

G.J. Keighery 424, PERTH 3621286 , CANB 370637

G.J. Keighery 431, PERTH 3621421

G.J. Keighery 492, PERTH 1867547

G.J. Keighery 494, PERTH 3621243

G.J. Keighery 653, KPBG

G.J. Keighery 677, PERTH 3621189

G.J. Keighery 2248, PERTH 3621383

G.J. Keighery 2887, PERTH 3621448

G.J. Keighery 2165,PERTH 3620859

G.J. Keighery 104, PERTH 4878752

G.J. Keighery 673, PERTH 3628590

G.J. Keighery s.n

G.J. Keighery 78 
The specimens which were found to be $n=10$ occur in the south-west of Western Australia, north from Nannup, whereas specimens from the south coast of Western Australia, east from Nannup, and the one specimen from South Australia are $n=20$ (Fig. 3). However, no consistent morphological differences were found to correlate with the different chromosome numbers in either species.

Xanthosia huegelii was previously considered to be restricted to Western Australia; however as here circumscribed it is also found in South Australia and Victoria, where it was previously treated as X. pusilla. Xanthosia tasmanica also occurs in Western Australia, where it constitutes Keighery's unnamed subspecies 'Southern' within $X$. huegelii, as well as occurring in South Australia, Victoria, New South Wales and Tasmania. Table 2 summarises the names previously applied to each species in each state of their distribution.

\begin{tabular}{|c|c|c|}
\hline State & Xanthosia huegelii & Xanthosia tasmanica \\
\hline Western Australia ${ }^{1}$ & $\begin{array}{l}\text { X. huegelii subsp. huegelii } \\
X . \text { huegelii subsp. aurea MS. } \\
X . \text { pusilla }\end{array}$ & X. huegelii subsp. 'Southern' MS. \\
\hline South Australia² & $X$. pusilla & X. tasmanica \\
\hline Victoria $^{3}$ & X. pusilla & X. pusilla \\
\hline Tasmania4 & - & X. pusilla \\
\hline New South Wales 5 & - & misidentified as $X$. pilosa \\
\hline
\end{tabular}

\section{Key to the trifoliolate-leaved herbaceous species of Xanthosia}

1 Stems excorticating when aged; leaf segments linear to oblong or lanceolate; fruit with 5-9 ribs 1. X. huegelii

$1^{*}$ Stems not excorticating when aged; leaf segments elliptic, the lateral segments sometimes bifid; fruit with 5-7 ribs 2. X. tasmanica

\section{Taxonomy}

1. Xanthosia huegelii (Benth.) Steud., Nomencl. bot. 2: 791 (1841).

Leucolaena huegelii Benth. in Endl. et al., Enum. pl., 55 (1837).

Type: Western Australia: Swan River, Hügel (lecto, here chosen, K!; isolecto W, photo!). Bentham's protologue cites 'King Georges Sound et Swan River. (Hügel)', however, only material labelled 'Swan River, Hügel' has been located. As this material clearly fits the details of the protologue it is here designated as the lectotype.

Xanthosia glabrata Bunge in Lehm., Pl. Preiss. 1: 290 (1845).

Xanthosia pusilla var. glabrata (Bunge) Benth., Fl. Austral. 3: 361 (1867).

Type: In umbrosis sylvae ad fluvium Canning, Perth, Western Australia, Nov 1841, Herb. Preiss. No. 2076 (holo P; iso MEL!). 


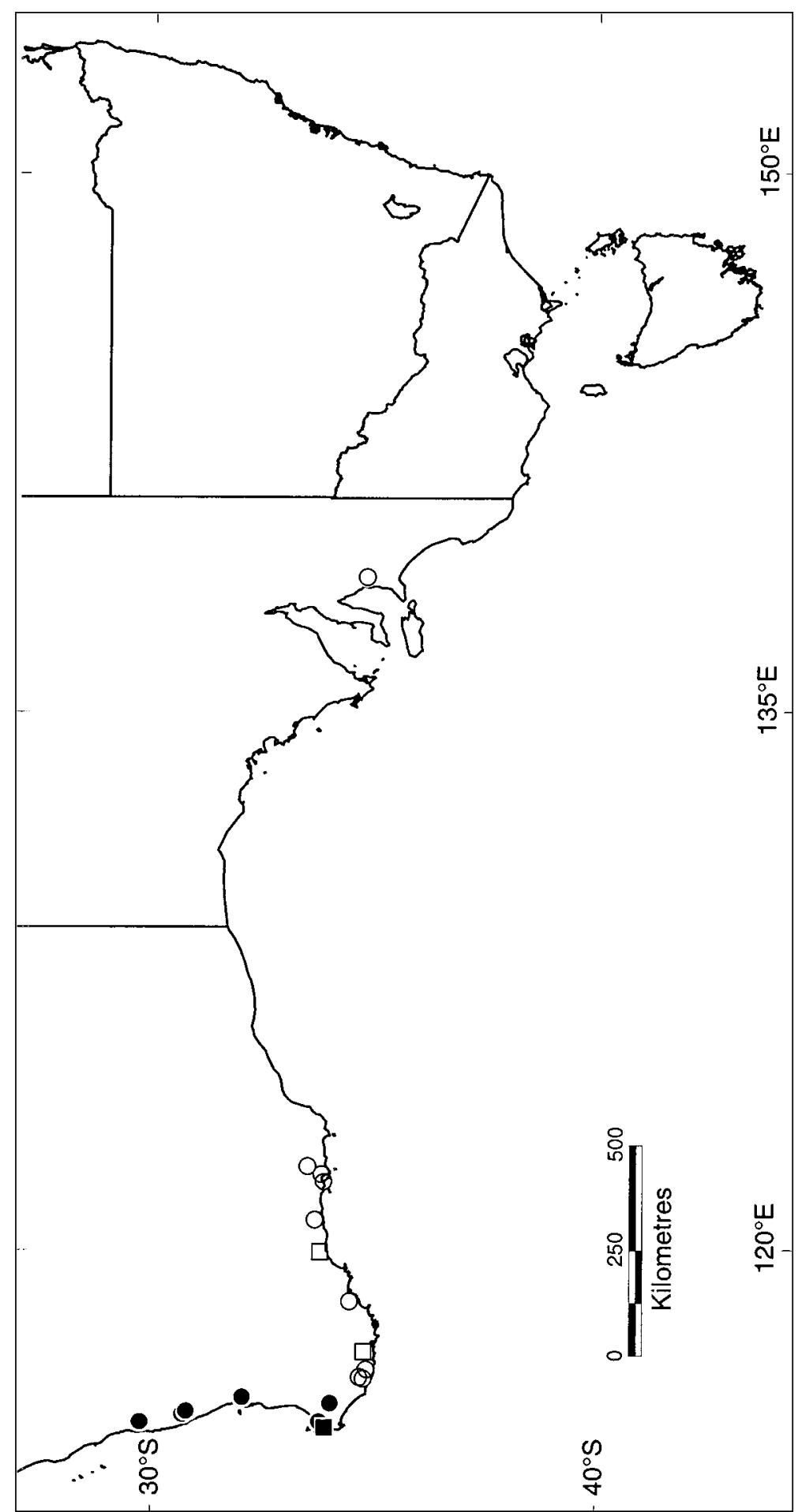

Fig. 3. Distribution of chromosome voucher specimens for X. huegelii $(\bullet n=10, \mathbf{0} n=20)$ and X. tasmanica Domin ( $\mathbf{\square} n=10, \square n=20)$. 
Xanthosia pusilla Bunge in Lehm., Pl. Preiss. 1: 291 (1845).

Type: In arenosis humidis umbrosisque ad fluvium King's-River, Plantagenet, Western Australia, 14 Oct 1840, Herb. Preiss. No. 2078 (holo P; iso MEL!).

Xanthosia villosa Turcz., Bull. Soc. Imp. Nat. Moscou 22(2): 32 (1849).

Type: Western Australia: Swan River, J. Drummond IV. n. 139 (lecto, here chosen, KW, photo!; isolecto BM!, K!). Turczaninov's type designation is discussed under Taxonomic History.

Erect or ascending perennial herb, 5-20 cm high. Plant near glabrous to densely villous, the stem excorticating when aged. Leaves cauline, trifoliolate. Petiole sheathing shortly at the base to entirely sheathing, 1-7 $\mathrm{mm}$ long. Leaflets linear, oblong, lanceolate or oblanceolate, the segments equal, very rarely lobed, 4-38 mm long, 1-10 mm wide; margins entire; apex acute. Inflorescence a compound umbel with 1-4 rays, sometimes contracted and appearing simple, 1-6 flowers per ray and up to 3 flowers between the rays; the flowers all bisexual to bisexual and male. Rays terete, to $5 \mathrm{~mm}$ long. Involucral bracts 1-4, elliptic or linear, foliaceous, green, longer than the rays, 3-9 mm long, 1-4 mm wide; apex acute or obtuse. Bracteoles 2 or 3, elliptic or linear, foliaceous, green, shorter to longer than the flowers, 4-6 mm long, 1-3 mm wide; apex acute or obtuse. Inflorescences sessile or pedunculate; peduncles to $25 \mathrm{~mm}$ long. Flowers pedicellate. Sepals ovate, 1.1-2.9 mm long, 0.7-1.4 mm wide, green; base truncate; apex acute, glabrous. Petals equal to sepals, $1-1.2 \mathrm{~mm}$ long, $0.3-0.6 \mathrm{~mm}$ wide, white; midrib adaxially keeled and bridged; apex acute or obtuse; appendage smooth. Stamens approximately equal to the perianth. Nectaries raised and prominent, $0.4-0.7 \mathrm{~mm}$ high, cream, hirsute. Styles $0.7-1.9 \mathrm{~mm}$ long. Ovary hirsute. Male flowers different from bisexual ones in having undeveloped inconspicuous ovary, with styles barely protruding above nectaries. Fruit brown, ovoid, 2.3-2.8 mm long, 1.9-2.3 mm wide, 0.4-0.7 mm deep. Monocarps villous on the summit, rarely glabrous, oblong in transverse section, 5-9 ribbed; the ribs keeled. Chromosome number $n=10$ and $n=20$ (Keighery 1982; Table 1). (Fig. 4).

Flowering: most of the year.

Notes: Xanthosia huegelii is a variable species particularly in indumentum and inflorescence size. A variant with dense greyish indumentum, broader bracteoles and a greater number of flowers per umbellule occurs in Western Australia around Eneabba and south to Perth, with intergrading forms south of Perth. Placement of specimens into any form-groups is largely arbitrary.

Distribution: coast and adjacent ranges in Western Australia (between Eneabba and Esperance), South Australia (on the Eyre Peninsula, Kangaroo Island and east from the Lofty Ranges) and south-western Victoria (the Grampians to Wilsons Promontory) (Fig. 5).

Ecology: widespread in forest and heath usually on sandy soils.

Selected Specimens (over 200 examined): Western Australia: 6 miles [c. $10 \mathrm{~km}$ ] N of junction of Eneabba South road with Coorow-Green Head road, Chapman s.n., 30 Aug 1977 (PERTH 3260611); $0.5 \mathrm{~km}$ N of Marchagee Track W of Brand Highway, Cranfield 8892 \& Kabay, 3 Sept 1993 (PERTH); $14.6 \mathrm{~km}$ along the Mooliabeenee road from the Great Northern Highway towards Gingin, Hart 95055, 25 Oct 1995 (PERTH, SYD); Delta road, Walpole-Nornalup National Park, Hart 95108, 8 Nov 1995 (PERTH, SYD); Porongorups, $1.3 \mathrm{~km}$ along Angwin Park road from Bolganup road, Hart 95129, 13 Nov 1995 (PERTH, SYD); $2.8 \mathrm{~km}$ along the South Coast Highway from Chester Pass road towards Jerramungup, Hart 95134, 15 Nov 1995 (SYD); Lucky Bay, Cape Le Grand National Park, Hart 95142, 18 Nov 1995 (SYD); Eneabba, Humphreys 342, 21 Sept 1966 (PERTH); Keighery 5366, Oct 1975 (PERTH); Gold Holes, Chester Pass, Stirling Ranges, Keighery 5533, 19 Oct 1982 (PERTH); Goode Beach area, Torndirrup National Park, $18 \mathrm{~km} \mathrm{~S}$ of Albany, Keighery 8513, 5 Nov 1986 (PERTH); Cape Le Grand National Park E of Esperance, Royce 8713, 21 Oct 1969 


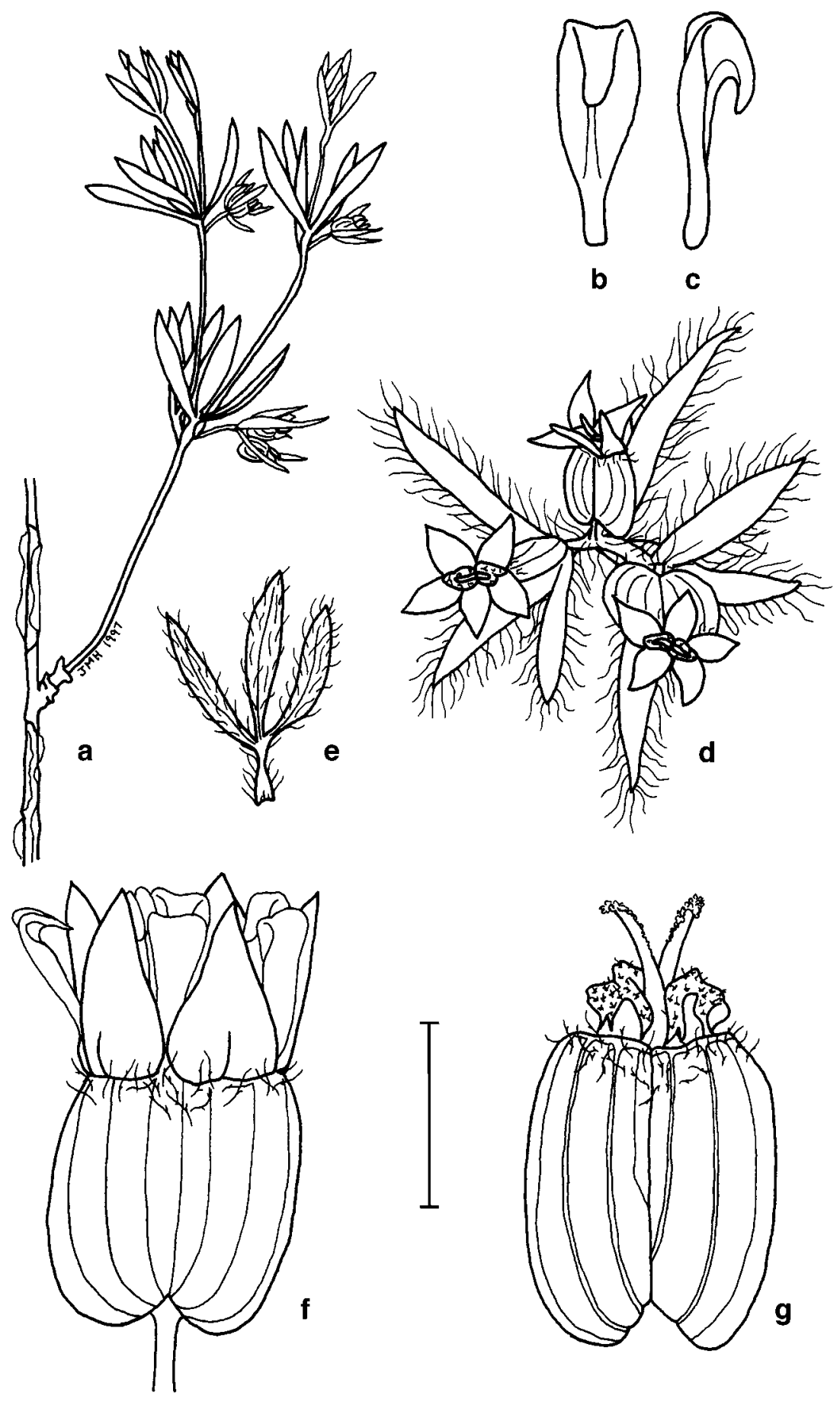

Fig. 4. Xanthosia huegelii. a, branchlet; b, c, petals, (b, adaxial view; c, side view); d, inflorescence, two single-flowered rays with one flower between the rays; $\mathbf{e}$, leaf; $\mathbf{f}$, bisexual flower; $\mathbf{g}$, fruit (from Hart 379). Scale bar: $\mathrm{a}=25 \mathrm{~mm} ; \mathrm{b}, \mathrm{c}=0.8 \mathrm{~mm} ; \mathrm{d}=4 \mathrm{~mm}$; $=20 \mathrm{~mm} ; \mathrm{f}=1.2 \mathrm{~mm} ; \mathrm{g}=1.5 \mathrm{~mm}$. 
(PERTH); Blue Waters, Collie, Saffrey 1763, 1 Nov 1979 (CANB, K, PERTH); Helena Valley, Seabrook 271, 25 Sept 1977 (PERTH); Station road Walpole-Nornalup National Park, Wheeler 3159, 13 Aug 1992 (PERTH).

South Australia: Hundred of Wanilla, Section 124 Reserve [c. $25 \mathrm{~km} \mathrm{NNW}$ of Port Lincoln], Alcock 798, 17 Oct 1965 (AD); Big Heath National Park c. $1.5 \mathrm{~km} \mathrm{~S}$ and parallel to the fire break, midnarrow neck (c. 25 km SW Naracoorte), Alcock 2913, 4 Nov 1969 (AD); 4 km SW of Bradbury on the western side of Mt Bold road, Donner 9721, 3 Nov 1983 (AD); Kangaroo Island on Bark Hut road near Amen Corner, Jackson 3167, 21 Nov 1993 (AD); Start of track $6.6 \mathrm{~km}$ S of Ashbourne by road, Coxs Scrub Conservation Park, Hart 381, 23 Nov 1996 (AD, SYD).

Victoria: $6.5 \mathrm{~km}$ N of Portland-Nelson road on Wrights Swamp road, Hart 379, 21 Nov 1996 (MEL, SYD); Slopes between Great Ocean road and Harvey Street Anglesea, Smith 59/288, 1 Nov 1959 (MEL).

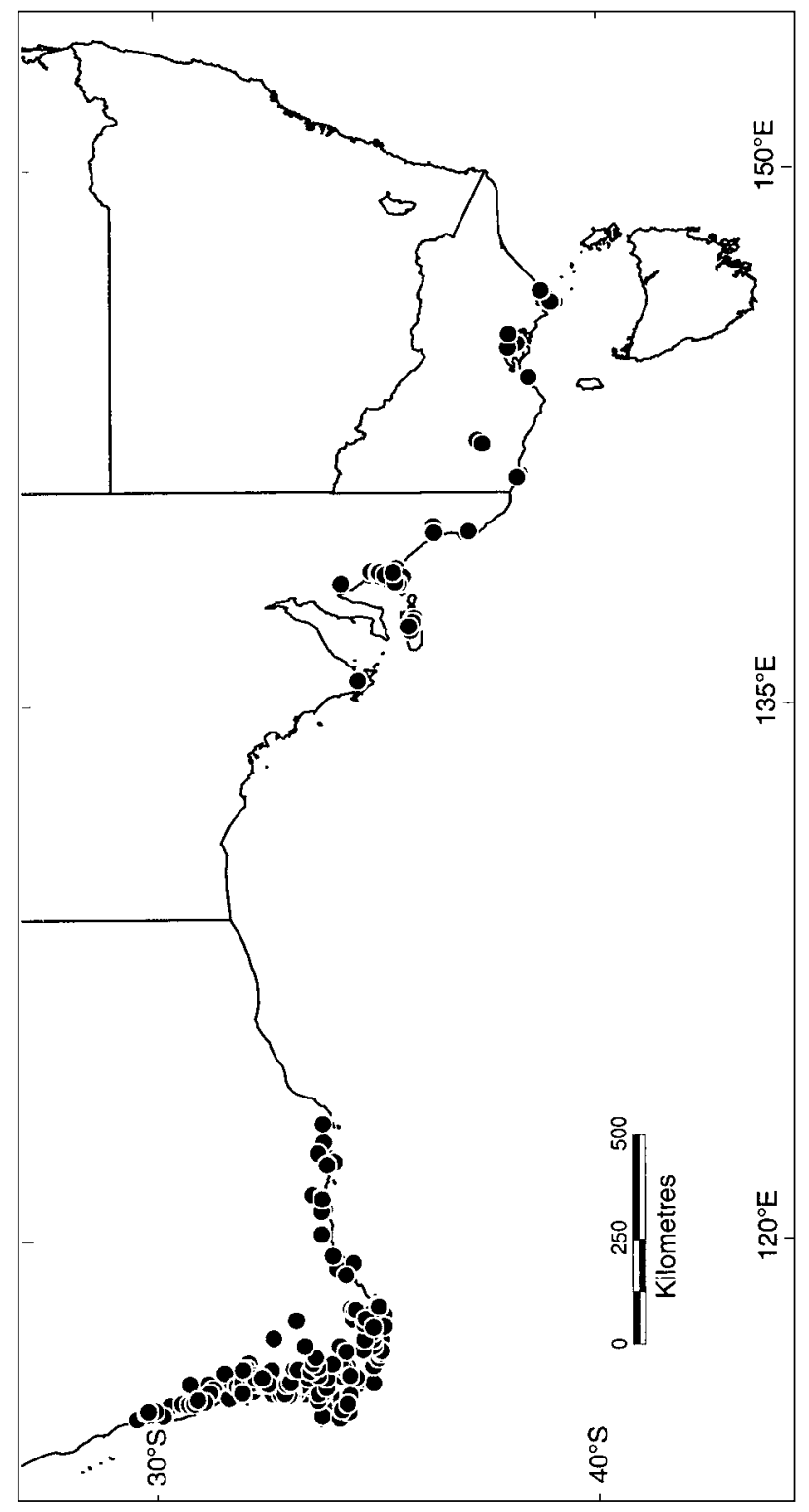

Fig. 5. Distribution of Xanthosia huegelii $(\mathbb{\bigotimes})$ based on locality information from herbarium specimens. 
2. Xanthosia tasmanica Domin, Repert. Spec. Nov. Regni Veg. 4: 298 (1907) non Gand., Bull. Soc. Bot. France 65: 32 (1918).

Type: Circular Head, Tasmania, R. Gunn 1837 / 879 (lecto, here chosen, K!, the largest specimen in the top left corner). Domin cited two specimens in the protologue for X. tasmanica; 'prope George Town (lg. Gunn 1842 sub no. 1122) et Circular Head (lg. Gunn 1837 sub no. 879) (H. Kewense)'. This material, comprising nine elements, is mounted on a single sheet at $\mathrm{K}$. Thus there is some ambiguity as to which collection(s) were from George Town and which were from Circular Head. The largest element, in the top left corner, has a determinavit label below it by Dr Hansjoerg Eichler (dated 1961) indicating his intention to lectotypify this plant (which he never published). The nearest locality label to this plant is for the Circular Head collection. This largest plant is designated as lectotype (in accordance with Dr Eichler's intentions) as it is the best specimen on the sheet.

Erect or ascending perennial herb to $20 \mathrm{~cm}$ high. Plants covered by sparse, long, spreading hairs. Leaves cauline, trifoliolate. Petiole sheathing shortly at the base, sheaths 1-8 mm long. Petiole to $30 \mathrm{~mm}$ long, angular, grooved above or flattened. Leaflets elliptic, the segments equal or the lateral leaflets split or parted almost to the base, 4-15 mm long, 3-8 mm wide, shortly petiolulate; margins entire; apex acute. Inflorescence a compound umbel with 1-4 rays, sometimes contracted and appearing simple, one flower per ray and up to one flower between the rays; the flowers all bisexual. Rays terete, 1-3 mm long. Involucral bracts 1-4, linear, foliaceous, green, longer than the rays, 3-4 mm long, $1 \mathrm{~mm}$ wide; apex acute. Bracteoles two or three, linear, foliaceous, green, shorter than flowers, 3-4 mm long, $1 \mathrm{~mm}$ wide; apex acute. Inflorescences sessile or pedunculate; peduncles to $5 \mathrm{~mm}$ long. Flowers pedicellate. Sepals ovate, 2-2.5 mm long, c. $1 \mathrm{~mm}$ wide, green; base truncate; apex acute, glabrous. Petals shorter than sepals, c. $1.2 \mathrm{~mm}$ long, c. $0.5 \mathrm{~mm}$ wide, white; midrib adaxially keeled or keeled and bridged; apex acute; appendage smooth. Stamens shorter than perianth. Nectaries raised and prominent, c. $0.3 \mathrm{~mm}$ high, white or yellow, hirsute. Styles 1-1.5 mm long. Ovary hirsute. Fruit brown, ovoid, c. $2.1 \mathrm{~mm}$ long, c. $2.3 \mathrm{~mm}$ wide, $0.6 \mathrm{~mm}$ deep. Monocarps hirsute on the summit, elliptic in transverse section, $5-7$ ribbed; the ribs keeled or not elevated. Chromosome number $n=10$ or $n=20$ (Keighery 1982; Table 1). (Fig. 6).

Flowering: most of the year, peaking in spring.

Distribution: found in south-west Western Australia, Fleurieu Peninsula and Kangaroo Island in South Australia, the Grampians and coastal Victoria to the far south coast of New South Wales, and coastal Tasmania (Fig. 7).

Ecology: occurring mainly in coastal areas in heath or forest on sandy soils.

Selected Specimens (60 examined): Western Australia: Delta road, Walpole-Nornalup National Park, Hart 95109, 8 Nov 1995 (PERTH, SYD); 25 km NW Denmark on Walpole road [ $n=20]$, Keighery 673,12 Oct 1974 (PERTH); 18 miles [29 km] S of turnoff to Busselton on Yallingup to Karridale road [ $n=10]$, Keighery 2165, 29 Oct 1972 (PERTH).

South Australia: 5.6 km NW Pardana, Kangaroo Island, Lang \& Maguire NPKI30860, 19 Nov 1989 (AD); Mount Lofty Range, Spring Mount c. 8 km SE of Myponga, Whibley 1710, 23 Nov 1966 (AD).

Victoria: East Gippsland, Croajingolong National Park near mouth of Seal Creek, Albrecht 4846, 22 Oct 1991 (AD, HO, MEL); Marlo-Cape Conran road at Point Ricardo turnoff, Hart 369, 18 Nov 1996 (MEL, SYD).

New South Wales: Green Cape Lighthouse 26 km SE of Eden, Coveny 5811 \& Armstrong, 16 Oct 1974 (K, L, MEL, NSW, UC).

Tasmania: Edwards road, Arve, Allan s.n., 22 Dec 1980 (HO 39283); Heath west of Bridport, Morris 8188, 13 Oct 1981 (HO, MEL). 

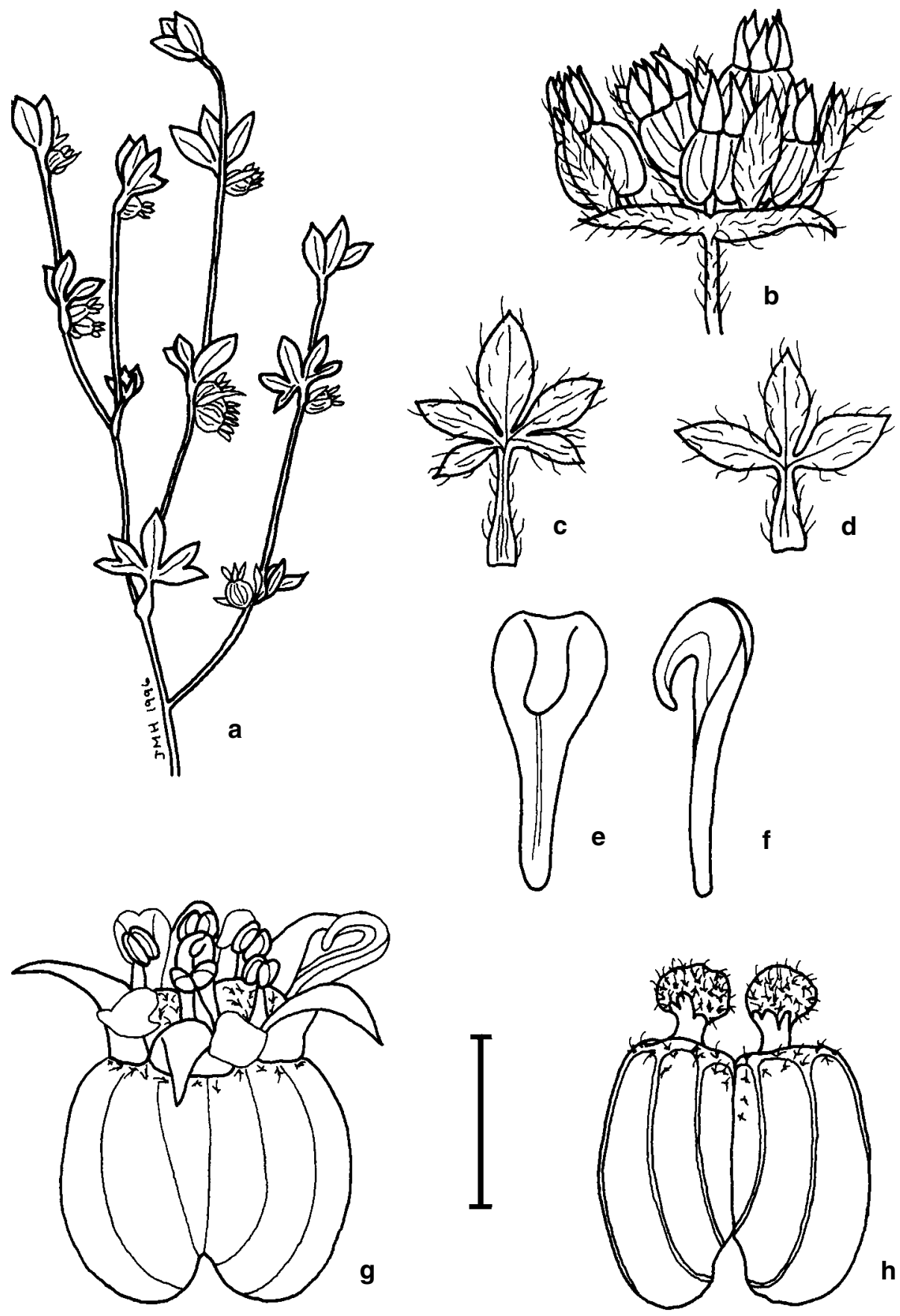

Fig. 6. Xanthosia tasmanica: a, branchlet; b, inflorescence; $\mathbf{c}, \mathbf{d}$, leaves showing variation; e, f, petals, (e, adaxial view; f, side view); g, bisexual flower; $\mathbf{h}$, fruit (from Hart 95109). Scale bar: $\mathrm{a}=40 \mathrm{~mm} ; \mathrm{b}=5 \mathrm{~mm} ; \mathrm{c}, \mathrm{d}=20 \mathrm{~mm} ; \mathrm{e}, \mathrm{f}=0.75 \mathrm{~mm} ; \mathrm{g}=1.6 \mathrm{~mm} ; \mathrm{h}=1.5 \mathrm{~mm}$. 


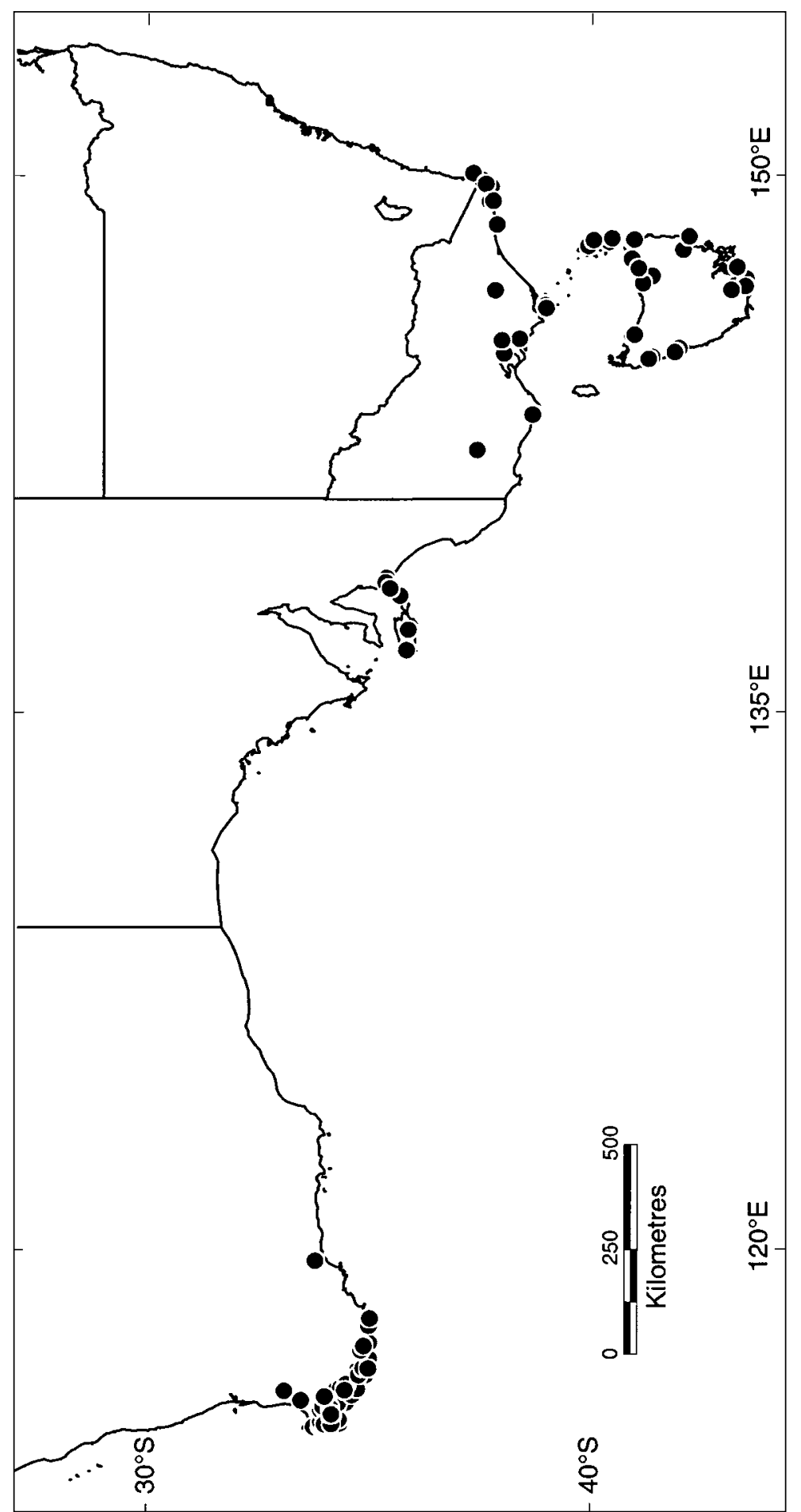

Fig. 7. Distribution of Xanthosia tasmanica $(\bigotimes)$ based on locality information from herbarium specimens. 


\section{Acknowledgments}

The directors and staff of AD, CANB, CBG, HO, KPBG, MEL, NSW and PERTH for access to and/or loans of specimens, particularly Neville Marchant for allowing me to examine his photos of the Xanthosia villosa type in KW. Murray Henwood and Bob Makinson are thanked for critical review of the manuscript.

\section{References}

Bentham, G. (1837) Umbelliferae. Pp. 55-56 in Endlicher, S.L., Fenzl, E., Bentham, G. and Schott, H.W. (eds), Enumeratio plantarum quas in Novae Hollandiae ora austro-occidentali ad fluvium cygnorum et in sinu Regis Georgii collegit Carolus Liber Baron de Hügel. (Fr. Beck: Vienna).

Bentham, G. (1867) Flora Australiensis, vol. 3. (L. Reeve: London).

Brooks, A.K. \& Powell, J.M. (1992) Xanthosia (Apiaceae). Pp. 94-96 in Harden, G.J., (ed.) Flora of New South Wales, vol. 3. (New South Wales University Press: Sydney).

Bunge, A.A. von (1845) Umbelliferae. Pp 282-295 in Lehmann, J.G.C., Plantae Preissianae, vol. 1. (Meissner: Hamburg).

Curtis, W.M. (1963) The Student's Flora of Tasmania, Part 2. (Govt Printer: Tasmania).

Domin, K. (1907) Umbelliferae novae extraeuropaeae. I. Repert. Spec. Nov. Regni Veg. 4: 298.

Eichler, H. (1986) Umbelliferae (Apiaceae). Pp. 979-1010 in Jessop, J.P. \& Toelken, H.R. (eds), Flora of South Australia. Part II Leguminosae - Rubiaceae. (South Australian Government Printing Division: Adelaide).

Keighery, G.J. (1982) Chromosome numbers of Western Australian Apiaceae. J. Roy. Soc. Western Australia 65: 143-145.

Marchant, N.G. (1990) The contribution of the Russian botanist Turczaninov to Australian plant taxonomy. Pp. 121-130 in Short, P.S. (ed.), History of Systematic Botany in Australia. (Australian Systematic Botany Society Inc.: Melbourne).

Ostenfeld, C.H. (1921) Contributions to West Australian Botany. Part III. Additions and notes to the Flora of extra-tropical W. Australia. Biol. Meddel. Kongel. Danske Vidensk. Selsk. 3(2): 101, 102.

Rye, B.L. (1999) A taxonomic revision of the many-flowered species of Trachymene (Apiaceae) in Western Australia. Nuytsia 13: 193-232.

Steudel, E.G. von (1841) Nomenclator Botanicus, edn 2, 2.

Turczaninov, N.S. (1849) Bull. Soc. Imp. Nat. Moscou 22: 3-38.

Wheeler, J.R. (1987) Apiaceae. Pp. 501-518 in Marchant, N.G., Wheeler, J.R., Rye, B.L., Bennett, E.M., Lander, N.S., \& Macfarlane, T.D. (eds), Flora of the Perth Region, Part 1. (Western Australian Herbarium, Department of Agriculture: Perth).

Willis, J.H. (1978) A Handbook to Plants in Victoria, vol. 2. (Melbourne University Press: Melbourne).

Manuscript received 22 April 1999

Manuscript accepted 22 March 2000 
